\title{
PENINGKATAN HASIL BELAJAR MATERI PENYESUAIAN MAKHLUK HIDUP DALAM PEMBELAJARAN KOOPERATIF METODE THINK-PAIR-SHARE DIPADU DENGAN METODE PICTURE AND PICTURE PADA SISWA KELAS V-A SD MUHAMMADIYAH 8 DAU MALANG
}

\author{
Citra Marina ${ }^{1}$, Ainur Rofieq ${ }^{1}$, Sri Wahyuni, \\ ${ }^{1}$ Program Studi Pendidikan Biologi, FKIP, Universitas Muhammadiyah Malang \\ email: biologi.umm@gmail.com
}

\begin{abstract}
From interviews result, we can say $45 \%$ of the number of students has a low learning outcomes. The research purposes are: To determine the increase in the learning material adjustment Beings through cooperative learning combined the TPS method with $P \& P$ method at the VA graders SD Muhammadiyah 8 Dau Malang. Implementation of TPS learning combined with $P \& P$ already performing optimally. Based on the results of correcting data analysis sheet formative test on cycle-3 students who scored $>$ SKM as many as 27 people (90\%), whereas the received value <SKM value of 3 people (10\%) of 30 students.
\end{abstract}

Keywords: Think-Pair-Share (TPS), Picture and Picture (P\&P), Cooperative

Pembelajaran IPA di SD merupakan interaksi antara siswa dengan lingkungan sekitarnya. Hal ini mengakibatkan pembelajaran IPA perlu mengutamakan peran siswa dalam kegiatan belajar mengajar. Sehingga pembelajaran yang terjadi adalah pembelajaran yang berpusat pada siswa dan guru sebagai fasilitator dalam pembelajaran tersebut. Guru berkewajiban untuk meningkatkan pengalaman belajar siswa untuk mencapai tujuan pembelajaran IPA. Tujuan ini tidak terlepas dari hakikat IPA sebagai produk, proses dan sikap ilmiah. Oleh sebab itu, pembelajaran IPA perlu menerapkan prinsip-prinsip pembelajaran yang tepat.

Guru juga sangat menentukan keberhasilan siswa, terutama dalam proses belajar mengajar. Ketepatan menggunakan metode akan sangat mempengaruhi hasil belajar siswa. Guru dapat menggunakan metode pembelajaran yang memotivasi siswa untuk belajar agar dapat meningkatkan hasil belajar. Metode pembelajaran yang digunakan dalam pembelajaran IPA sangat banyak. Tiap metode pembelajaran memiliki kelebihan dan kekurangan yang berbeda, tidak semua metode pembelajaran dapat digunakan guru untuk penyampaian materi IPA.

Hasil wawancara pada tanggal 3 Nopember 2011 dengan guru mata pelajaran IPA di SD Muhammadiyah 8 Dau Malang, bahwa dari 31 orang siswa pada kelas V A, dapat dikatakan $45 \%$ dari jumlah siswa memiliki hasil belajar yang rendah. Selain itu, guru pengajar mengaku jarang menggunakan media pembelajaran seperti gambar-gambar hewan, tumbuhan dll. Guru juga mengatakan bahwa jarang menggunakan pembelajaran berbasis kerjasama dikarenakan siswa lebih banyak diam apabila ditugaskan untuk berdiskusi dalam kelompok. Siswa seringkali kesulitan memberikan jawaban dari pertanyaan-pertanyaan guru apabila pertanyaan tersebut dikaitkan dengan fakta yang ada dilingkungan dan materi yang disampaikan.

Pembelajaran

kooperatif (Cooperative Learning) merupakan sistem pengajaran yang memberi kesempatan kepada anak didik untuk bekerja sama dengan sesama siswa dalam tugas-tugas yang terstruktur. Pembelajaran kooperatif dikenal dengan pembelajaran secara berkelompok. Tetapi belajar kooperatif 
lebih dari sekedar belajar kelompok atau kerja kelompok karena dalam belajar kooperatif ada struktur dorongan atau tugas yang bersifat kooperatif sehingga memungkinkan terjadinya interaksi secara terbuka dan hubungan yang bersifat interdepedensi efektif diantara anggota kelompok (Sugandi, 2002:14 dalam Aryawan 2009). Keunggulan Think-PairShare (TPS) adalah memberi rangsangan kepada siswa untuk berpikir sehingga bermanfaat bagi proses pendidikan jangka panjang (Suprijono, 2009). Keunggulan Picture and Picture (P\&P) adalah guru lebih mengetahui kemampuan masingmasing siswa dan melatih berpikir logis (Depdiknas, 2007).

Berdasarkan hasil wawancara, maka peneliti dalam penelitian ini memutuskan untuk menggunakan pembelajaran kooperatif. Pembelajaran kooperatif yang dipilih adalah metode TPS karena metode ini dirasa lebih tepat untuk kegiatan berpikir, berpasangan dan berbagi sesuai kegiatan yang akan dilakukan siswa. TPS cenderung bersifat abstrak karena mengandalkan kemampuan berpikir siswa, sedangkan metode P\&P cenderung bersifat konkrit maka dari itu pembelajaran TPS ini sangat cocok dipadukan dengan metode P\&P karena seusia anak SD cenderung berpikir konkrit.

Kegiatan akan diawali dengan memberikan pertanyaan kepada siswa terkait materi penyesuaian makhluk hidup termasuk tahap Think. Selanjutnya siswa menempelkan beberapa gambar dan mengisi tabel yang sudah disediakan pada kertas buffalo secara berpasangan (Pair). Sehingga dengan menggunakan pembelajaran metode TPS yang dipadukan dengan metode $\mathrm{P} \& \mathrm{P}$ diharapkan dapat meningkatkan hasil belajar siswa. Kemudian hasil dari pemikiran menempelkan gambar dan mengisi tabel yang sudah ada pada kertas buffalo, masing-masing pasangan kemudian akan mempresentasikan di depan kelas sebagai tahap Share

\section{METODE}

Penelitian ini merupakan penelitian tindakan kelas (PTK) yang dilakukan secara bersiklus. Desain penelitian terdiri atas empat tahap, yaitu perencanaan, pelaksanaan tindakan, observasi dan evalusi, serta refleksi yang diikuti pengualangan. Penelitian tindakan kelas ini difokuskan pada hasil belajar siswa menggunakan pembelajaran kooperatif metode TPS dipadukan dengan metode P\&P. Menurut Isjoni (2010), TPS memberi siswa kesempatan untuk bekerja sendiri serta bekerja sama dengan orang lain. Tipe pembelajaran ini memberikan siswa waktu lebih banyak untuk berfikir, menjawab, dan saling membantu satu sama lain. Sedangkan menurut Arisandi (2011), P\&P menggunakan media gambar dalam proses pembelajaran yaitu dengan cara memasang/mengurutkan gambar-gambar menjadi urutan yang logis.

Penelitian ini akan dilaksanakan di SD Muhammadiyah 8 DAU pada bulan Nopember - Desember 2011. Penelitian ini yang menjadi subyek penelitian adalah siswa kelas V A SD Muhammadiyah 8 DAU tahun pelajaran 2011/2012. Materi/konsep yang diajarkan dalam pembelajaran penyesuaian makhluk hidup terhadap lingkunganya.

Data yang akan dikumpulkan dalam penelitian ini adalah (1) Data tentang proses pembelajaran, meliputi pelaksanaan pembelajaran kooperatif metode TPS yang dipadukan dengan metode P\&P, aktivitas guru, aktivitas siswa selama proses pembelajaran. Sumber datanya diperoleh dari aktivitas pembelajaran, aktivitas guru, serta aktivitas siswa selama proses pembelajaran. (2) Data tentang hasil belajar siswa pada materi penyesuaian makhluk hidup. Sumber datanya diperoleh dari siswa yang berupa hasil tes formatif siswa pada akhir pembelajaran.

Analisis data hasil test formatif menggunakan PAP artinya penentuan nilai seorang siswa dilakukan dengan jalan membandingkan skor mentah hasil tes 
dengan skor maksimum idealnya dan akan digunakan rumus sebagai berikut:

$$
\text { Nilai tes }=\frac{\text { Skor Mentah }}{\text { Skor Maksimum Ideal }} \times 100 \%
$$

Menurut Mulyasa (2009), kriteria keberhasilan jangka pendek adalah sekurang-kurangnya $75 \%$ isi dan prinsipprinsip pembelajaran dapat dipahami, diterima dan diterapkan oleh para siswa dan guru dikelas. Rumus untuk mengetahui ketuntasan klasikal adalah sebagai berikut:

$$
\text { Ketuntasan klasikal }=\frac{m}{M} \times 100 \%
$$

Keterangan :

$\mathrm{m}=\sum$ siswa yang memperoleh nilai di atas KKM

$\mathrm{M}=\sum$ seluruh siswa yang mengikuti tes

Dikatakan berhasil apabila 85\% dari jumlah siswa dikelas memiliki ketuntasan individu $\geq$ SKM yaitu 70 .

\section{HASIL}

Kegiatan pembelajaran, baik pada siklus I, II, maupun siklus III, menerapkan metode Think Pair Share dipadupadankan dengan Picture \& Picture. Pada siklus I materi penyesuaian hewan dengan lingkunganya proses pembelajaran hasil refleksi banyak siswa tidak bisa memberikan respon yang cukup baik, selain itu beberapa siswa kurang aktif. Oleh karena itu keterlaksanaan sintaks pada siklus I kurang optimal. Hal ini nampak pada hasil belajar siswa dari 25 siswa yang mengikuti tes, ada 9 siswa yang memperoleh nilai tes formatif di atas $\mathrm{SKM} \geq 70$, sementara ada 16 siswa yang memperoleh nilai tes formatif di bawah SKM yaitu $<70$, sementara ketuntasan individu di siklus-1 sebesar $36 \%<85 \%$, maka siswa dinyatakan belum tuntas belajar secara klasikal dapat dilihat pada tabel berikut. Selain itu, Persentase aktivitas guru selama proses pembelajaran $=78,15 \%$ berada pada kategori baik. Rata- rata persentase aktivitas siswa dari lima indikator penilaian selama proses pembelajaran $=75 \%$ berada pada kategori baik

Tabel 1. Nilai Ketuntasan Klasikal Siklus-1

\begin{tabular}{cccc}
\hline Ketuntasan & Kriteria & $\begin{array}{c}\text { Jumlah } \\
\text { siswa }\end{array}$ & $\begin{array}{c}\text { Presentase } \\
(\%)\end{array}$ \\
\hline Ketuntasan Individu & $<70$ & 16 & $64 \%$ \\
& $\geq 70$ & 9 & $36 \%$ \\
Ketuntasan Klasikal & $>85 \%$ & 16 & $36 \%$ \\
\hline
\end{tabular}

Pada siklus II dilakukan penyempurnaan sintaks pada siklus II untuk pengutan kembali penerapan pembelajaran metode TPS yang dipadukan dengan P\&P yang kurang optimal pada saat pelaksanaan siklus-1. Materi yang disampaikan untuk pertemuan kali ini adalah penyesuaian diri hewan untuk melindungi diri dari musuhnya. Berdasarkan hasil pengoreksian lembar jawaban soal tes formatif untuk hasil belajar (Gambar 1) dapat diketahui bahwa masing-masing siswa memiliki pemahaman konsep yang berbeda-beda.

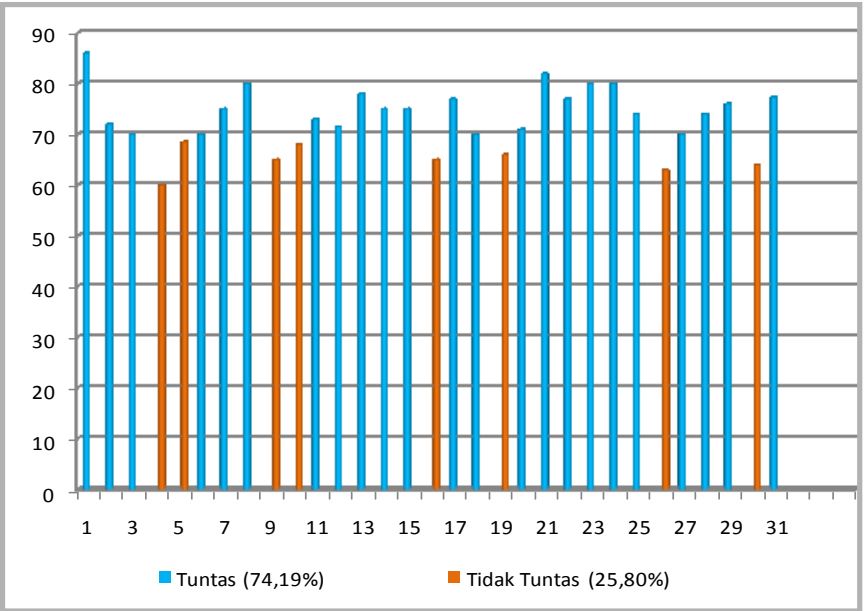

Gambar 1. Ketuntasan Nilai Hasil Belajar Siswa Siklus-2

Berdasarkan data pada Gambar 1 dapat diketahui bahwa dari 31 siswa yang mengikuti tes, ada 23 siswa yang memperoleh nilai tes formatif di atas SKM $\geq 70$, sementara ada 8 siswa yang memperoleh nilai tes formatif di bawah SKM yaitu $<70$, sementara ketuntasan klasikal di siklus-2 sebesar 74,19\% <85\%, 
maka siswa dinyatakan belum tuntas secara klasikal.

Tabel 2. Nilai Ketuntasan Klasikal Siklus-2

\begin{tabular}{cccc}
\hline Ketuntasan & $\begin{array}{c}\text { Kriteri } \\
\text { a }\end{array}$ & $\begin{array}{c}\text { Jumlah } \\
\text { siswa }\end{array}$ & $\begin{array}{c}\text { Presentase } \\
(\%)\end{array}$ \\
\hline Ketuntasan Individu & $<70$ & 8 & $25,80 \%$ \\
& $\geq 70$ & 23 & $74,19 \%$ \\
Ketuntasan Klasikal & $>85 \%$ & 23 & $74,19 \%$ \\
\hline
\end{tabular}

Persentase aktivitas guru selama proses pembelajaran $=82,6 \%$ berada pada kategori baik. Rata-rata persentase aktivitas siswa dari lima indikator penilaian selama proses pembelajaran $=$ $75,36 \%$ berada pada kategori baik. Untuk keterlaksanaan sintaks pembelajaran sudah dapat dikatakan optimal karena dari 9 sintaks pembelajaran 8 sintaks sudah terlaksana dengan baik. Aktivitas siswa sudah meningkat dibandingkan pada pelaksanaan siklus-1. Hasil refleksi untuk upaya optimalisasi kegiatan pembelajaran selanjutnya

Pada siklus III ini dilakukan untuk memperbaiki dan menyempurnakan tindakan-tindakan yang kurang optimal pada saat pelaksanaan siklus-2. Materi yang disampaikan untuk pertemuan kali ini adalah penyesuaian diri tumbuhan untuk kelangungan hidupnya dan melindungi diri dari musuhnya. Berdasarkan hasil test formatif hasil belajar disusun Gambar 2 sebagai berikut.

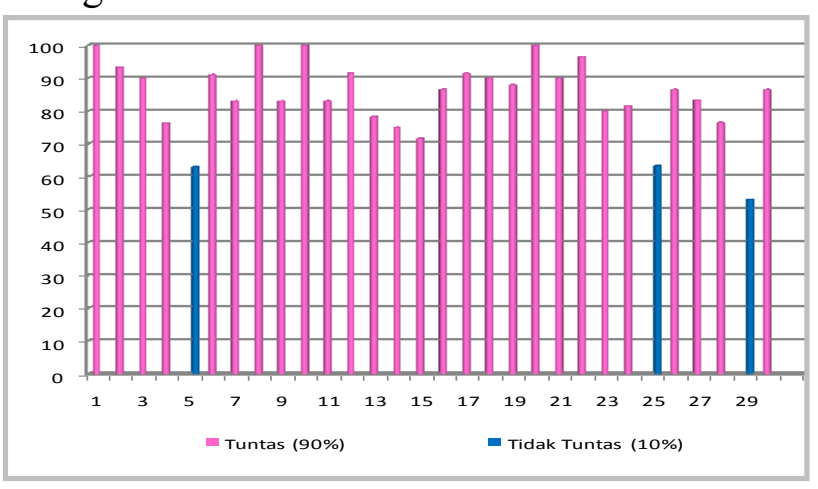

Gambar 2. Ketuntasan Nilai Hasil Belajar Siswa Siklus-3

Berdasarkan data pada Gambar 2 dapat diketahui bahwa dari 30 siswa, ada 27 siswa yang memperoleh nilai tes formatif diatas SKM $>70$, sementara ada 3 siswa yang memperoleh nilai tes formatif dibawah SKM yaitu $<70$. Ketuntasan klasikal $85 \%$ dari 30 siswa adalah $>25$ siswa, sementara ketuntasan individu sebesar $90 \%>85 \%$, maka siswa dinyatakan sudah tuntas belajar secara klasikal. Persentase aktivitas guru selama proses pembelajaran $=82,85 \%$ berada pada kategori baik. Rata-rata persentase aktivitas siswa dari lima indikator penilaian selama proses pembelajaran $=$ $82,4 \%$ berada pada kategori baik.

Tabel 3. Nilai Ketuntasan Klasikal Siklus-3

\begin{tabular}{cccc}
\hline Ketuntasan & Kriteria & $\begin{array}{c}\text { Jumlah } \\
\text { siswa }\end{array}$ & $\begin{array}{c}\text { Presentase } \\
(\%)\end{array}$ \\
\hline Ketuntasan Individu & $<70$ & 3 & $10 \%$ \\
& $\geq 70$ & 27 & $90 \%$ \\
Ketuntasan Klasikal & $>85 \%$ & 25 & $90 \%$ \\
\hline
\end{tabular}

\section{PEMBAHASAN}

Penerapan pembelajaran metode TPS yang dipadukan dengan P\&P pada kelas VA SD Muhammadiyah 8 DAU diawali dengan memberikan pertanyaan yang dituliskan dipapan tulis terkait materi penyesuaian diri tumbuhan dan merupakan tahap Think. Pembelajaran yang diawali dengan pertanyaan menuntut siswa untuk berpikir berdasarkan pengalaman mereka sehari-hari tidak hanya dari buku pelajaran. Pembelajaran ini juga memberi siswa waktu lebih banyak untuk berfikir, menjawab, dan saling membantu satu sama lain (Isjoni, 2010).

Perpaduan metode TPS dengan metode P\&P sangat mendukung khususnya untuk pembelajaran di Sekolah Dasar. Untuk seusia anak SD sangat menggemari gambar-gambar yang full colour, dan itu akan berdampak positif bagi proses pembelajaran mereka dalam memahami suatu konsep. Media gambar memiliki peranan penting dalam meningkatkan hasil belajar siswa. Hal ini mengacu pada pernyataan Winataputra (2005) dalam Hamdani (2010), yang menyatakan bahwa penglihatan (visual) memiliki komposisi yang paling besar 
(75\%) dalam hal rata-rata jumlah informasi yang dapat diperoleh seseorang. Informasi yang diperoleh melalui penglihatan juga lebih mudah ditangkap dan diingat oleh memori seseorang.

Penerapan pembelajaran seperti ini memberikan pengalaman belajar kepada siswa untuk berpikir berdasarkan pengalaman mereka sehari-hari, berdiskusi, serta mempresentasikan hasil karya mereka dalam menempelkan gambar dan mengisi tabel penyesuaian makhluk hidup. Dengan demikian, pembelajaran seperti ini bersifat sangat berpusat pada siswa dan hal ini menyebabkan siswa menjadi sangat aktif dalam dan memberikan suasana yang tidak membosankan pada kegiatan pembelajaran. Menurut Arends (1997) dalam Triyanto, menyatakan bahwa ThinkPair-Share merupakan suatu cara yang efektif untuk membuat variasi suasana pada diskusi kelas.

Berdasarkan

keterlaksanaan

pembelajaran metode TPS dipadukan dengan metode $\mathrm{P} \& \mathrm{P}$ yang berlangsung dalam pelaksanaan siklus-1, siklus-2 dan siklus-3 diketahui bahwa tahapan-tahapan dalam pelaksanaan metode pembelajaran TPS yang dipadukan dengan metode P\&P telah terlaksana dengan baik serta sesuai dengan sintaks pembelajaran yang diaplikasikan dalam Rencana Pelaksanaan Pembelajaran (RPP). Hal ini terbukti dengan adanya peningkatan keterlaksanaan tiap-tiap tahapan pembelajaran. Pada siklus-1, keterlaksanaan sintaks pembelajaran belum optimal, ada 2 sintaks terlaksana kurang baik. Berdasarkan kriteria yang ditentukan bahwa pembelajaran dikatakan optimal apabila dari 8 sintaks perpaduan minimal 7 sintaks terlaksana dengan baik. Pada siklus-2, ada sedikit perubahan sintaks dari sintaks sebelumnya. Keterlaksanaan sintaks pembelajaran pada siklus-2 sudah optimal karena pada pelaksanaan siklus-2 merupakan perbaikan dari upaya optimalisasi pelaksanaan siklus-1. Dari 9 sintaks pada pembelajaran siklus-2, 8 sintaks sudah terlaksana dengan baik. Tetapi tetap harus dilakukan upaya optimalisasi sintaks yang terlaksana kurang baik tersebut pada tahap tindakan siklus-3, sehingga pada pelaksanaan tindakan diharapkan semua sintaks terlaksana dengan baik. Hal tersebut terbukti bahwa pada pelaksanaan tindakan siklus-3, semua sintaks terlaksana dengan baik.

Persentase aktivitas guru selama proses pembelajaran pada siklus-3= $82,85 \%$ berada pada kategori baik. Hal ini dikarenakan guru sudah terbiasa melaksanakan sintaks pembelajaran metode TPS yang dipadukan dengan metode P\&P sehingga guru tidak mengalamai kesulitan seperti halnya pada pelaksanaan pada siklus-1. Untuk perbandingan persentase aktivitas guru dari pelaksanaan siklus-1, siklus-2 hingga pelaksanaan siklus-3 dapat dilihat pada Gambar 3.



Gambar 3. Perbandingan Persentase Aktivitas Guru pada siklus-1, Siklus-2 dan siklus-3

Penerapan pembelajaran kooperatif metode TPS yang dipadukan dengan metode P\&P berorientasi pada peningkatan hasil belajar siswa, ternyata juga sangat efektif untuk meningkatkan aktivitas siswa. Hal ini dapat dilihat dari hasil 
penempelan gambar dan pengisian tabel penyesuaian makhluk hidup berdasarkan hasil diskusi kelompok dan dipresentasikan di depan kelas. Rata-rata persentase aktivitas siswa dari lima indikator penilaian selama proses pembelajaran tahap tindakan $=82,4 \%$ berada pada kategori baik. Lima indikator tersebut adalah: siswa aktif mengikuti pembelajaran sampai selesai, interaksi antar siswa dalam berpasangan, interaksi siswa-siswa antar pasangan, interaksi siswa dengan guru, dan interaksi siswa dengan media pembelajaran. Persentase aktivitas siswa berada pada kategori baik ini disebabkan karena siswa sudah memiliki pengalaman sebelumnya pada pelaksanaan siklus-1 dan siklus-2 dalam mengikuti tahapan-tahapan pembelajaran TPS yang dipadukan dengan P\&P. Untuk perbandingan persentase aktivitas siswa pada siklus-1, siklus-2 hingga pada pelaksanaan siklus-3 dapat dilihat pada grafik 4.5.

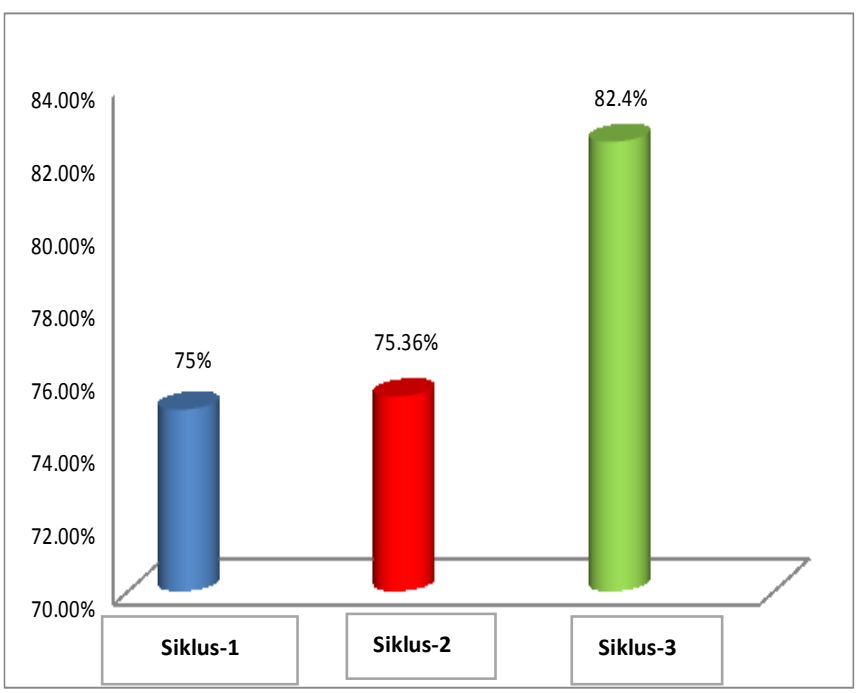

Gambar 4,. Perbandingan Persentase Aktivitas Siswa pada Siklus-1, Siklus-2 dan Siklus-3

Berdasarkan (Gambar 1, 2 dan 3), hasil belajar siswa terus meningkat hingga pada siklus-3 dapat diketahui bahwa siswa yang memperoleh nilai $>70$ sebanyak 27 orang $(90 \%)$, sedangkan yang mendapat nilai $<70$ sebanyak 3 orang $(10 \%)$ dari 30 siswa. Menurut Ayi (2010), hasil belajar merupakan hasil yang dicapai oleh siswa selama berlangsungnya proses belajar mengajar dalam jangka waktu tertentu. Menurut Dimyati dan Mudjiono (2002) hasil belajar merupakan hal yang dapat dipandang dari dua sisi yaitu sisi siswa dan dari sisi guru. Dari sisi siswa, hasil belajar merupakan tingkat perkembangan mental yang lebih baik bila dibandingkan pada saat sebelum belajar. Dari kedua pendapat diatas, maka dapat disimpulkan bahwa hasil belajar merupakan input yang didapatkan siswa setelah proses pembelajaran berlangsung. Siswa akan mendapatkan hasil belajar yang baik jika siswa melakukan proses pembelajaran dengan baik. Sebaliknya, jika siswa tidak sungguh-sungguh dalam proses pembelajaran, siswa akan mendapatkan hasil yang tidak sesuai dengan tujuan awal pembelajaran. Perbandingan hasil belajar siswa pada siklus-1, siklus-2, dan siklus-3 dapat dilihat pada Grafik 5 berikut.

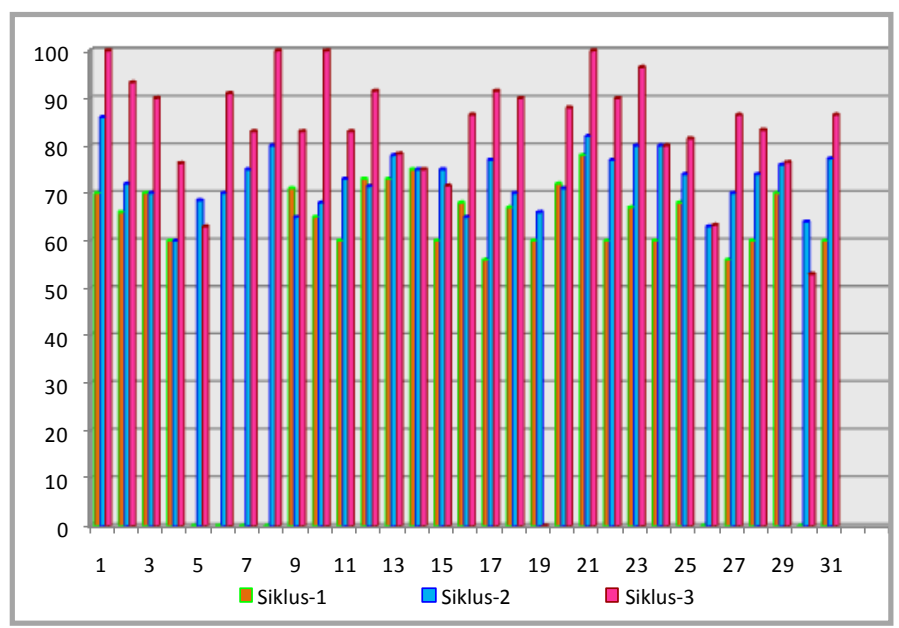

Gambar 5. Perbandingan Hasil Belajar Siswa Siklus-1, Siklus-2 dan Siklus-3

\section{KESIMPULAN DAN SARAN}

\section{Kesimpulan}

Peningkatan dan hasil belajar melalui penerapan pembelajaran kooperatif metode TPS yang dipadukan dengan metode P\&P dapat disimpulkan sebagai berikut: (1) Pada siklus-1 siswa yang memperoleh nilai $>$ SKM sebanyak 9 siswa $(36 \%)$, 
sedangkan yang memperoleh nilai $<$ SKM sebanyak 16 siswa (64\%) dari 25 siswa yang mengikuti tes. (2) Pada siklus-2 siswa yang memperoleh nilai $>$ SKM sebanyak 23 siswa $(74,19 \%)$, sedangkan yang mendapat nilai $<$ nilai SKM sebanyak 8 orang $(25,80 \%)$ dari 31 siswa yang mengikuti tes. (3) Pada siklus-3 siswa yang memperoleh nilai $>$ SKM sebanyak 27 orang $(90 \%)$, sedangkan yang mendapat nilai < nilai SKM sebanyak 3 orang $(10 \%)$ dari 30 siswa.

\section{Saran}

Penerapan pembelajaran kooperatif metode TPS yang dipadukan dengan metode P\&P sebaiknya sesuai dengan materi yang memiliki konsep-konsep terkait lingkungan sehari-hari dan materi yang membutuhkan media gambar sebagai media pembelajaran. Membuat soal untuk tes formatif yang terkait kehidupan seharihari agar siswa dapat berpikir lebih kritis dan dikaitkan dengan gambar-gambar sehingga menarik bagi siswa. Soal tes formatif yang dibuat dapat mencakup tingkatan $\mathrm{C} 1-\mathrm{C} 6$ sesuai dengan $\mathrm{KD}$ dan Indikator Pembelajaran.

\section{DAFTAR PUSTAKA}

Akbar, Ayi. 2010. Pengertian prestasi belajar, (Online), http://ayiakbar. com/ebook /artikel/ pengertianprestasi-belajar/, diakses 29 Oktober 2010)

Arisandi, 2011. Model Pembelajaran Picture and Picture. http:// arisandi .com $/ ? \mathrm{p}=786$
Bambang Aryawan, 2009. Pembelajaran Kooperatif (Cooperative Learning) Untuk Membangun Pengetahuan Siswa. http://riyadi.purworejo.asia /2009/07/pembelajaran-kooperatifcooperative .html Diakses 24 Juni 2011

Depdiknas. 2007. Materi Soialisasi Kurikulum Tingkat Satuan Pendidikan. Jakarta: Direktorat Jenderal Pendidikan Dasar dan Menengah

Dimyati., dan Mudjiono.2002.Belajar dan Pembelajaran. Jakarta:Dirjen Pendidikan Tinggi DEPDIKBUD

Hamdani, 2010. Efektifitas Pemanfaatan Media Gambar dalam Peningkatan Hasil Belajar pada Pembelajaran Sholat (Skripsi). Sekolah Tinggi Agama Islam DR. Khez Muttaqien Purwakarta

Isjoni.2010. Cooperative Learning Efektifitas Pembelajaran Kelompok. Bandung: Alfabeta.

Mulyasa. 2009. Praktik Penelitian Tindakan Kelas. Bandung: PT Remaja Rosdakarya

Suprijono, A. 2009. Cooperative Learning Teori Aplikasi \& Aplikasi Paikem. Yogyakarta: Pustaka Pelajar

Triyanto, Model - Model Pembelaran Inovatif Berorientasi Konstruktivistik; Konsep Landasan Teoritis - Praktis dan Implementasinya, Jakarta:Prestasi Pustaka Publisher, 2007 